\title{
Molecular Characterization and Population Structure Analysis of Pepper Mild Mottle Virus Infecting Capsicum in Himachal Pradesh, India
}

\author{
Kumari $\mathbf{N}^{1,2 *}$, Patel PB', Chaudhary $\mathbf{S}^{1}$ and Sharma \\ PN $^{1}$ \\ ${ }^{1}$ Department of Plant Pathology, CSK HPKV, Himachal \\ Pradesh, India \\ ${ }^{2}$ Division of Crop Protection, ICAR-Central Institute for \\ Subtropical Horticulture, Uttar Pradesh, India \\ *Correspondling author: Nidhi Kumari, Scientist, \\ Division of Crop Protection, ICAR-Central Institute \\ for Subtropical Horticulture, Rehmankhera, \\ Lucknow-226101, Uttar Pradesh, India
}

Received: September 01, 2021; Accepted: October 06, 2021; Published: October 13, 2021

\begin{abstract}
Pepper Mild Mottle Virus (PMMoV) is posing a great threat to capsicum cultivation worldwide. Based on the ability of PMMoV in overcoming $L$ mediated resistance in Capsicum spp., it has been categorized in to five pathotypes. The information of pathotype is crucial in framing sustainable management practices. The surveys conducted in seven districts of Himachal Pradesh (H.P) during 2016 and 2017 revealed maximum incidence of PMMoV in Kullu (88.89\%) district followed by Mandi (78.57\%) after confirmation through DAS-ELISA and RT-PCR. A total 16 isolates were selected for their pathotype characterization by deducing their Amino Acid (aa) sequence and their pathogenicity on differential capsicum cultivars carrying $L^{1}, L^{2}, L^{+}, L^{3}$ and $L^{4}$ genes. None of the test isolates produced visible symptoms on differential cultivarsPI-159236 and $\mathrm{PI}-260429$ carrying $L^{3}$ and $L^{4}$ genes, respectively. The aa sequences of all test isolates except PMMoV-16.6, 16.10 and PMMoV-17.1 were 100\% similar to the $P_{12}$ pathotypes available at NCBI database. Additionally, the 3-D structure of PMMoV-16.6, 16.10 and 17.1 isolates constructed using SWISSMODEL affirmed the presence of mutations in the short and long hairpin loops of viral CP corresponding to the inner surface and thus do not contribute to the elicitor activity of $\mathrm{CP}$. Thus, all the present isolates were characterized as $P_{12}$ pathotype. The full genome sequences of three isolates viz., PMMoV-16.7 (MN496153), 16.9 (MN496154) and 17.3 (MN734123) determined in the present study revealed their maximum similarity with PMMoV-HP1 $\left(\mathrm{P}_{12}, \mathrm{KJ} 631123.1\right)$ and a Japanese isolate $\left(P_{12}, A B 000709.2\right)$ and least with a Korean isolate (LC082100.1). The full genome-based recombination analysis did not show any significant recombination event.
\end{abstract}

Keywords: PMMoV; Capsicum; Pathotype; L gene; Coat protein

\section{Abbreviations}

PMMoV: Pepper Mild Mottle Virus; DAS-ELISA: Double Antibody Sandwich Enzyme Linked Immunosorbent Assay; RTPCR: Reverse Transcriptase Polymerase Chain Reaction; CP: Coat Protein; NCBI: National Center for Biotechnology Information

\section{Introduction}

Pepper Mild Mottle Virus (PMMoV), a Tobamovirus of Virgaviridae family is a major threat to Capsicum spp. cultivation across the world due to its wide prevalence, long term stability, highly contagious and seed borne nature. PMMoV was first described as a latent strain of Tobacco Mosaic Virus (TMV) in literature [1] but later isolated from peppers cultivated in Italy and designated as a distinct virus [2]. The occurrence of $\mathrm{PMMoV}$ is ubiquitous as its presence in abundance has been reported in different capsicum based processed food products, soil, drinking water, river water, sewage water, human feces yet in infective form $[3,4,5]$. In recent years this virus has also acquired attention from different group of workers worldwide as a potential water quality indicator [5]. PMMoV is a rigid $\sim 312 \mathrm{~nm}$ long rod-shaped positive sense single stranded RNA virus with $\sim 6.3 \mathrm{~kb}$ genome size. On pepper, this virus causes significant economic losses and the symptoms produced include mosaic and mottling on leaves and fruits, leaf puckering, thickening of vein, stunting, upward cupping of leaves, fruit deformations although sometimes remain unnoticed due to asymptomatic or mild leaf infection. PMMoV transmission takes place vertically through seed, plant to plant via contact, soil (a major source of inoculum for epidemics), and surface water, however, no insect transmission has been reported yet in case of PMMoV [6]. For the management of plant viruses, use of genetic resistance if durable is the most economic, target specific, highly efficient and best alternative approach with negligible deleterious effects to the environment [7]. The genetic resistance has been employed for plant virus management since more than 90 years and more than 200 genes conferring resistance have been identified in monocots, dicots, wild relative of crops and Arabidopsis spp. [8]. Pepper (Capsicum spp.) harbors L gene that conditions plant's resistance against tobamoviruses. There are 4 classical $L$ gene alleles named $L^{1}, L^{2}, L^{3}$ and $L^{4}$ which provide increasing recognition spectra and resistance against tobamoviruses $[9,10]$. In addition to these classical $L$ alleles, a new allele $L^{1 a}$ designated as $H k$ [11]. However, often virus mutant capable of overcoming existing resistance in host cultivar are encountered [12]. Different PMMoV pathotypes viz., $\mathrm{P}_{0}, \mathrm{P}_{1}, \mathrm{P}_{12}, \mathrm{P}_{123}$ and $\mathrm{P}_{1234}$ exist on the basis of its ability to overcome
Ann Agric Crop Sci - Volume 6 Issue 7 - 2021 ISSN: 2573-3583 | www.austinpublishinggroup.com Kumari et al. (C) All rights are reserved
Citation: Kumari N, Patel PB, Chaudhary S and Sharma PN. Molecular Characterization and Population Structure Analysis of Pepper Mild Mottle Virus Infecting Capsicum in Himachal Pradesh, India. Ann Agric Crop Sci. 2021; 6(7): 1097. 
$L^{1}, L^{2}, L^{3}$ and $L^{4}$ mediated resistance [10]. Alleles $L^{1}, L^{2}, L^{3}$ and $L^{4}$ characterized with localization of $\mathrm{P}_{0}$ pathotype of TMV in "Bruinsma Wonder" and "Verbeterde glas", both $\mathrm{P}_{0}$ and $\mathrm{P}_{1}$ pathotype in $C$. frutescense cv Tabasco, $\mathrm{P}_{0}, \mathrm{P}_{1}$ and $\mathrm{P}_{12}$ pathotypes in C. chinense and $\mathrm{P}_{0}, \mathrm{P}_{1}, \mathrm{P}_{12}$ and $\mathrm{P}_{123}$ strains of TMV in C. chacoense accession PI260429, respectively [13]. However, $L^{1 c}$ allele is characterized with localization of $\mathrm{P}_{0}$ pathotype at high temperature only. In addition to these classical $L$ alleles, a new allele $L^{1 a}$ designated as $H k$ gene showing resistance to not only $\mathrm{P}_{0}$ pathotype at any temperature but also Paprika mild mottle virus Japanese strain (PaMMV-J, P1) at $24^{\circ} \mathrm{C}$ [11]. With the increasing numbers of full genome determination in $\mathrm{PMMoV}$, different pathotypes capable of breaking $L^{2}, L^{3}$ and even $L^{4}$ mediated resistance are also reported [2,14-17]. Earlier workers have shown the role of single Amino Acid (aa) mutations in the Coat Protein (CP) gene of the virus in breaking $L$ mediated resistance in pepper, thus $\mathrm{CP}$ is designated as elicitor of $L$ mediated resistance in pepper against tobamoviruses $[18,19]$. Based on the chimera and mutation analysis it has been suggested that there exists a hierarchical interaction between tobamoviruses and $L$ gene due to the interaction between multiple Leucine Rich Repeats (LRR) domain's sub-regions of $L$ gene with different viral CP themselves or some protein complexes including them [20]. PMMoV has emerged as a great threat to the capsicum cultivation both in protected and open conditions in Himachal Pradesh (H.P.), India [21]. All the cultivars/capsicum hybrids like California wonder, Indira, Yolo wonder etc., famous among the farmers are susceptible to PMMoV. For undertaking breeding programme to introgress resistant genes in high yielding commercial cultivars as well as for the sustainable use of genetic resistance for its management, the knowledge of pathogen populations is of utmost importance. Thus, in this work we have analyzed and characterized the PMMoV populations from major capsicum growing areas of H.P. and identified their pathotypes(s) based on their pathogenic behavior on differential capsicum cultivars as well as $\mathrm{CP}$ gene and whole genome sequences.

\section{Materials and Methods}

\section{Surveys and collection of virus isolates}

In order to collect the virus isolates and assess the prevalence of pepper mild mottle disease, surveys of capsicum/chili crop cultivated under polyhouse and open field conditions were conducted in various districts of H.P. during 2016 and 2017. The districts surveyed included Kangra, Hamirpur, Bilaspur, Mandi, Kullu, Shimla and Solan. The plants were observed for the presence of virus like symptoms and insect vectors. The observation on disease incidence was recorded by counting the number of diseased plants in $2 \mathrm{~m}^{2}$ area at four locations in each polyhouse/field and per cent incidence was calculated as:

Disease Incidence $=\frac{\text { Number of diseased plants }}{\text { Total number of plants observed }} \times 100$

Total 97 diseased samples were collected from plants expressing virus like symptoms. The leaf samples properly wrapped in aluminum foil and packed in plastic bag with proper labeling were brought to the laboratory and stored at $-20^{\circ} \mathrm{C}$ till future use.

\section{Virus identification through DAS-ELISA and RT-PCR}

The presence of $\mathrm{PMMoV}$ in the diseased samples was determined through DAS-ELISA using commercially available PMMoV specific antibodies (Bioreba, Switzerland) [22]. Further confirmation of PMMoV association with the infected samples was done through RT-PCR using CP specific primers (CPF: 5' CCAATGGCTGACAGATTACG 3', CPR: 5' CAACGACAA CCCTTCGATTT 3') [6]. Once the presence of virus has been confirmed as PMMoV, the virus culture was maintained on susceptible capsicum variety "California wonder" by inoculating through standard leaf rub method and kept in insect free greenhouse at $23 \pm 2^{\circ} \mathrm{C}$ following proper precautions to avoid any contamination.

\section{Pathogenic Variability}

\section{Identification of PMMoV pathotypes}

The differential varieties comprising of Capsicum spp. viz., C. annuum (Yolo wonder), C. frutescense (Tabasco), C. annuum (Doux des Landes), C. chinense (PI-159236) and C. chacoense (PI260429) having tobamovirus resistance genes viz., $L^{1}, L^{2}, L^{+}, L^{3}$ and $L^{4}$, respectively were procured from The Centro de Investigacion and Tecnologia Agroalimenatria de Aragon (CITA), Spain through National Bureau of Plant Genetic Resources (NBPGR), New Delhi. Five plants of each differential variety were inoculated through standard leaf rub method at 4-5 leaf stage and 2 plants inoculated with plain water were kept as control in greenhouse at temperature $23 \pm 2^{\circ} \mathrm{C}$ and observed for the appearance of symptoms. The plants showing symptoms as well as those which were asymptomatic were subjected to DAS-ELISA to confirm the presence or absence of the virus.

\section{Coat Protein gene amplification, cloning and sequencing}

To identify the presence of various PMMoV strains in H.P., CP gene of each test isolates was amplified using CP specific primers [6]. The amplified regions of each test isolates were gel purified using Gel extraction kit (GeNei) following the manufacturer's instructions. The eluted PCR products representing the CP gene of all present isolates were ligated in pGEMT- Easy vector (Promega) and E. coli strain DH5 $\alpha$ cells were transformed using ligated product. Colony PCR was performed to confirm the presence of insert in randomly picked white colonies in case of each test isolate sample. Plasmid was isolated from recombinant transformed colonies through Alkali lysis method. Isolated plasmid was further screened by restriction digestion using restriction endonuclease EcoR1 and custom sequenced using the services of AgriGenome Labs. The sequences obtained were subjected to vecscreen to remove the vector sequences followed by NCBI nBLAST analysis. The sequences were translated through Expasy translate tool and the amino acid sequences of all the present isolates were observed for any single amino acid mutations and compared with the sequences of $\mathrm{P}_{12}, \mathrm{P}_{123}$ and $\mathrm{P}_{1234}$ pathotypes.

\section{Phylogenetic analysis}

The nucleotide sequences obtained after custom sequencing were first screened for vector sequences using vecscreen software and the sequences obtained were blasted using Blastn program (http:// www.ncbi.nih.gov/blast) to the confirm the identity as PMMoV at molecular level. The $\mathrm{CP}$ gene sequences of all the test isolates were compared with each other as well as other $\mathrm{CP}$ gene sequences available at NCBI databases. The multiple sequences were aligned by ClustalW program (https://www.genome.jp/tools-bin/clustalw) [23]. The CP gene nucleotide sequences of the present were translated using Expasy Translation Tool (www.expasy.org/tools/dna.html). The sequences were observed for single amino acid mutations 
A.

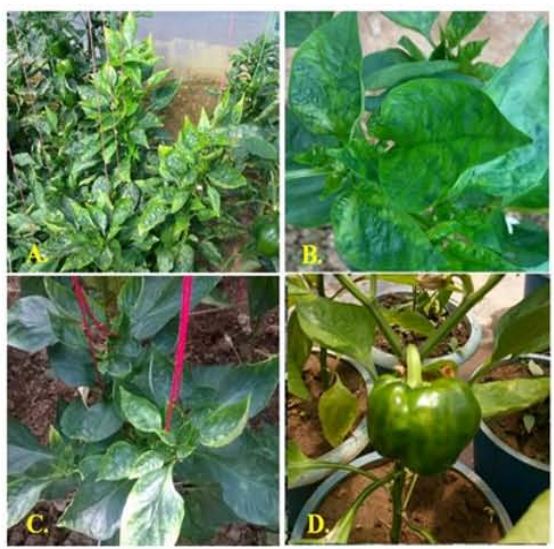

B.

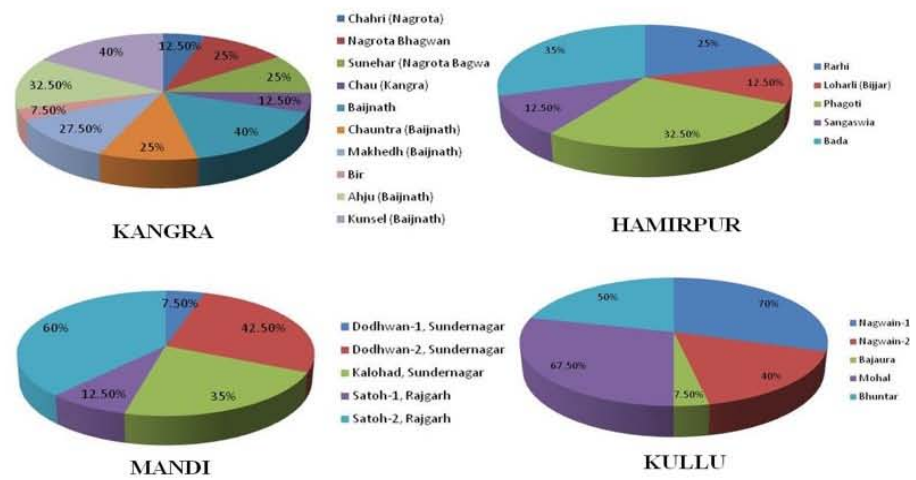

C.
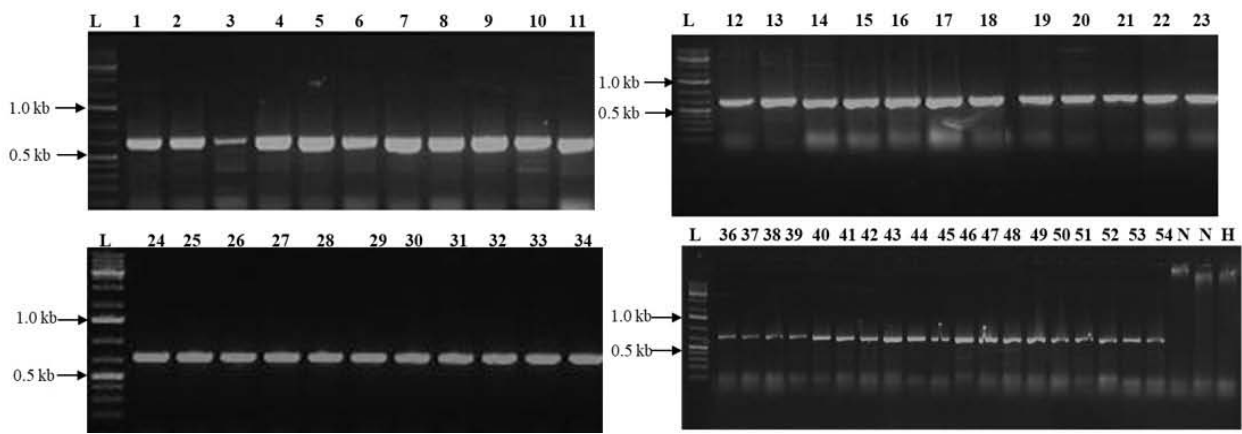

Figure 1: A) Symptomatology observed on capsicum plants during surveys conducted in 2016-17; B) Average Incidence of mild mottle disease based on the symptomatology in different districts of H.P.; C) Detection of PMMoV in diseased samples collected through RT-PCR using coat protein specific primers.

to determine the pathotype of $\mathrm{PMMoV}$ isolates. The amino acid sequences of present isolates were compared with that of known PMMoV pathotypes obtained from NCBI database and aligned using ClustalW program (https://www.genome.jp/tools-bin/clustalw) [23] and observed for the single amino acid mutations. The amino acid sequences of the present isolates were used to construct the threedimensional structure of coat protein using SWISS Model and viewed using SWISS-Pdbviewer 4.1.0 to locate the position of single amino acid substitutions in the present isolates.

\section{Determination of complete genome sequence}

Three isolates PMMoV-16.7, 16.9 and 17.3 from Sundernagar (Mandi), Nagwain (Kullu) and Phagli (Shimla), representing three districts were selected at random and their complete nucleotide sequence was determined [6]. The whole genome was assembled using DNAstar package (DNASTAR' Inc., USA).

\section{Full genome based phylogenetic and recombination analysis}

Four full PMMoV genome sequences of HP isolates ( 3 isolates sequenced in present study and one PMMoV-HP1(KJ631123) sequenced [6] along with other 25 full genomes present in NCBI database were aligned using MUSCLE alignment and a phylogenetic tree was constructed through neighbor joining method in GENEIOUS Prime software. To predict the recombination events and breakpoints based on PMMoV full genomes, RDP4 program with RDP, BOOTSCAN, GENECONV, CHIMAERA, MAXIMUM CHI SQUARE, SISCAN, and 3SEQ recombination detection methods was used. The analysis was carried out with default options for general recombination detection options. The events which were detected with at least four methods were considered plausible evidences for recombination.

\section{Results and Discussion}

\section{Surveys and collection of viral isolates}

During 2016-17, surveys were conducted in 29 locations of Kangra, Hamirpur, Bilaspur, Mandi, Kullu, Shimla and Solan districts of HP to assess the prevalence of disease and collect the viral isolates. The diseased plants in various polyhouses exhibited symptoms like mosaic, mottling, chlorosis, upward or downward curling and deformation of leaves along with stunting of plants (Figure 1A). The fruits beared by diseased plants were deformed and had lumpy appearance with mosaic pattern on their surface making them unfit for market. Based on the symptomatology, maximum incidence of 70 per cent was observed in Kullu district, followed by Mandi with 60 per cent incidence (Figure 1B). The prevalence of mites and white fly was observed in all the polyhouses. The attack of white fly was much more in those cases where the capsicum and tomato crops were being cultivated together. The prevalence of symptoms like upward cupping of young leaves along with puckering was high where the mite attack was severe.

\section{Virus identification}

Based on symptoms alone it is very difficult to conclude the presence of $\mathrm{PMMoV}$ in diseased samples as more than 20 viruses are 
A.

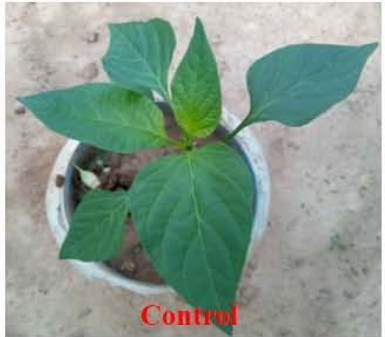

C.

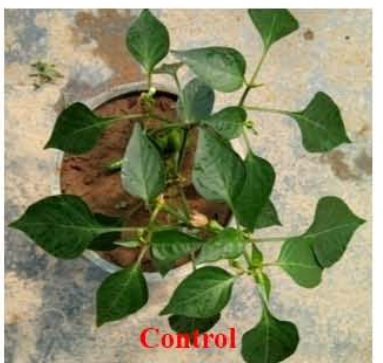

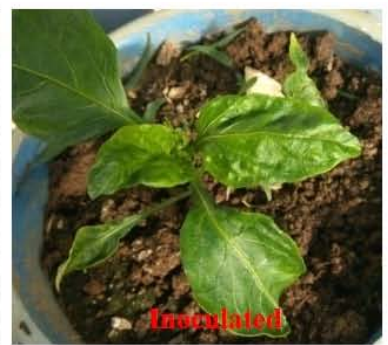

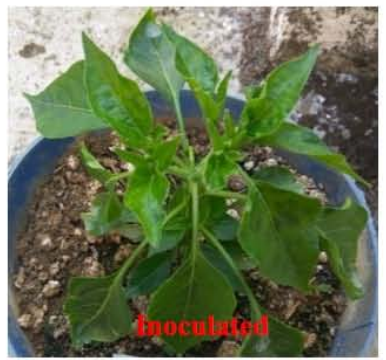

B.

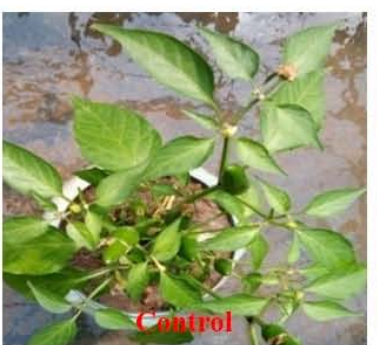

D.

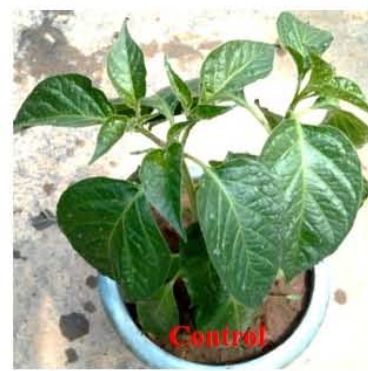

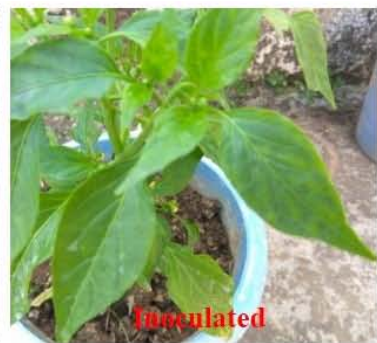

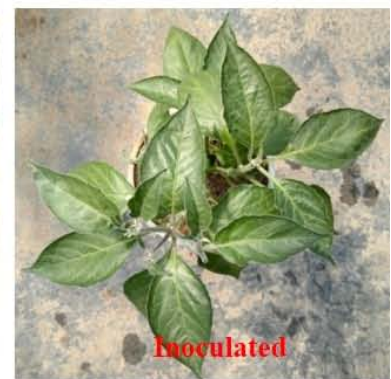

E.
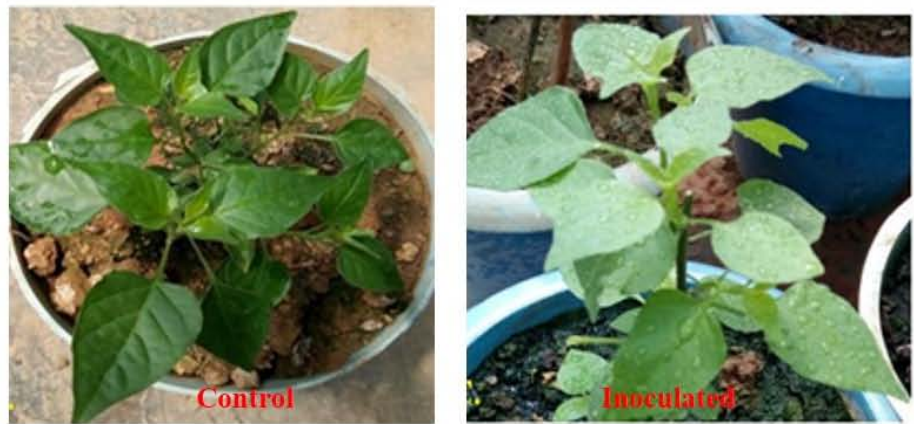

Figure 2: Symptoms observed on $C$. annuum (Yolo wonder) harboring $L^{1}$ allele A), C. frutescense Tabasco plants harboring $L^{2}$ allele B), $C$. annuum (Doux des Landes) harboring $L^{+}$allele C), C. chinense Pl-159236 harboring $L^{3}$ allele D), and C. chacoense (PI-260429) harboring $L^{4}$ allele $E$ ) following inoculations from present isolates.

known to infect capsicum that cause considerable quantity and quality losses in capsicum, exhibiting similar symptoms [24]. Therefore, the virus detection using DAS-ELISA and RT-PCR was carried out to affirm the presence of the target virus in the diseased samples. The DAS ELISA results recorded as absorbance value at $405 \mathrm{~nm}$ of the positive as well as negative samples along with the district wise prevalence of the virus are presented in (Table S1). Out of 97 samples collected from symptomatic plants, 54 samples were found positive for PMMoV. The highest percentage of positive samples was obtained from Kullu (88.89\%) district followed by Mandi (78.57\%), Shimla (66.67\%), Bilaspur (63.64\%) and Hamirpur (42.86\%), respectively. In Kangra district, out of 22 samples only 6 samples were found to possess the virus, however, none of the samples collected from district Solan were found positive for PMMoV. Despite the presence of virus like symptoms some of samples did not react positively in DAS-ELISA which indicated that those symptoms were due to the involvement of either some other virus or mite/thrip infestation as their damage mimic the virus symptoms [25]. All the samples showing positive result in DAS-ELISA as well as randomly 2 negative samples were further subjected to RT-PCR (Figure 1C). All the positive samples yielded an amplicon of $\sim 743 \mathrm{bp}$ while none of the negative samples showed any amplification, therefore confirmed the results of DASELISA.

\section{Pathogenic variability of PMMoV on differential varieties}

Isolates from different locations or from samelocation but showing variable symptoms were included in the present study (Table S2). The pathogenic reaction did not differ significantly between replicates for any given isolate. All the present isolates were able to infect and produce visible symptoms on 3 differential cultivars having $L^{1}, L^{2}$ and $L^{+}$genes. Typical virus symptoms were produced upon inoculation of all the present isolates on C. annuum (Yolo wonder, $L^{1}$ ), C. frutescense (Tabasco, $L^{2}$ ) and C. annuum (Doux des Landes, $L^{+}$) plants (Figure $2 \mathrm{~A}, \mathrm{~B}, \mathrm{C})$. All the isolates including PMMoV-16.7 and 16.9 which also resulted in reduced leaf lamina produced similar symtoms on all the 3 differential varieties. However, none of the isolates produced symptoms on C. chinense (PI-159236, L3) and C. chacoense (PI$\left.260429, L^{4}\right)$ plants which were comparable to the uninoculated plants kept as control (Figure 2D and E). The presence/absence of PMMoV in inoculated plants of each differential cultivar was established by indexing with DAS-ELISA and the absorbance values for each cultivar is given in (Table 1). Negative reaction was observed in case of C. chinense (PI-159236) and C. chacoense (PI-260429) bearing $L^{3}$ and $L^{4}$ gene, respectively. Hence based on the pathogenic response of the present isolates on differential cultivars, all the isolates collected from capsicum growing areas of HP were grouped in pathotype $\mathrm{P}_{12}$ 
A.

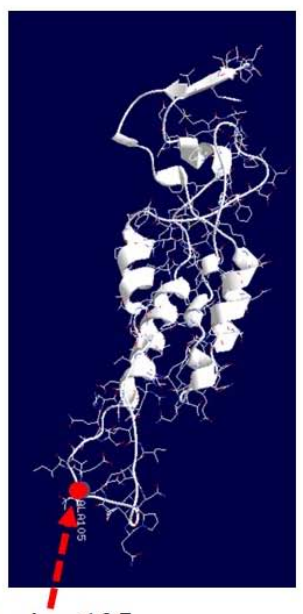

Alanine 105
B.

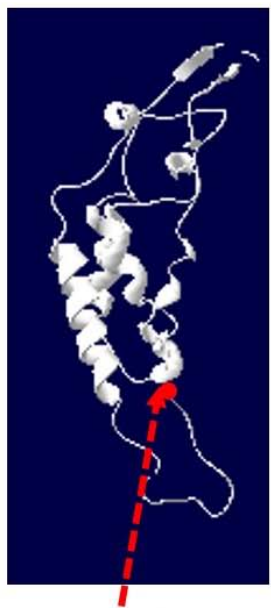

Lysine 91
C.

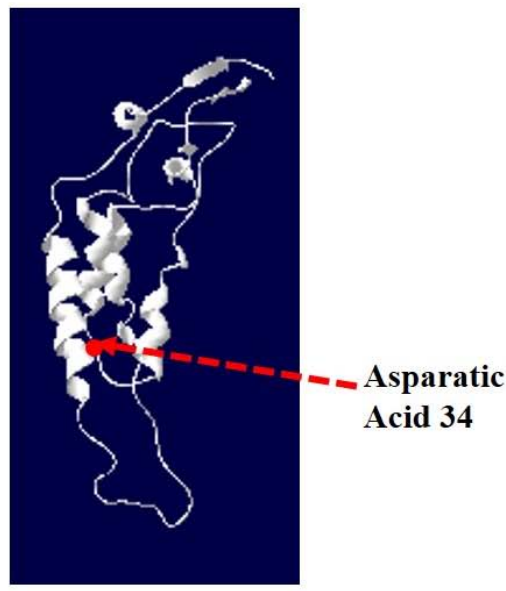

Figure 3: Three dimensional structure of $17 \mathrm{kDa}$ Coat Protein of PMMoV-16.6 (A), 16.10 (B) and 17.1 (C) constructed through SWISS Model and viewed using SWISS-Pdbviewer 4.1.0.

Table 1: Reaction of PMMoV isolates on differential cultivars vis-a-vis indexing through DAS-ELISA

\begin{tabular}{|c|c|c|c|c|c|c|c|c|c|c|c|c|}
\hline \multirow{3}{*}{ Isolates } & & & \multicolumn{10}{|c|}{ Differential Lines } \\
\hline & \multicolumn{2}{|c|}{ California wonder } & \multicolumn{2}{|c|}{101} & \multicolumn{2}{|c|}{102} & \multicolumn{2}{|c|}{103} & \multicolumn{2}{|c|}{104} & \multicolumn{2}{|c|}{105} \\
\hline & $\mathrm{A}_{405}$ & Reaction & $A_{405}$ & Reaction & $A_{405}$ & Reaction & $A_{405}$ & Reaction & $A_{405}$ & Reaction & $A_{405}$ & Reaction \\
\hline PMMoV-16.1 & 1.407 & + & 0.806 & + & 0.894 & + & 0.715 & + & 0.253 & - & 0.236 & - \\
\hline PMMoV-16.2 & 1.532 & + & 0.83 & + & 0.763 & + & 0.692 & + & 0.321 & - & 0.201 & - \\
\hline PMMoV-16.3 & 1.152 & + & 0.901 & + & 0.92 & + & 0.923 & + & 0.245 & - & 0.219 & - \\
\hline PMMoV-16.4 & 1.135 & + & 0.89 & + & 0.808 & + & 0.735 & + & 0.262 & - & 0.207 & - \\
\hline PMMoV-16.5 & 1.067 & + & 0.889 & + & 0.73 & + & 0.692 & + & 0.222 & - & 0.205 & - \\
\hline PMMoV-16.6 & 1.072 & + & 0.903 & + & 0.718 & + & 0.788 & + & 0.227 & - & 0.232 & - \\
\hline PMMoV-16.7 & 1.84 & + & 1.026 & + & 0.976 & + & 0.666 & + & 0.358 & - & 0.203 & - \\
\hline \multirow[t]{2}{*}{ PMMoV-16.8 } & 1.28 & + & 1.295 & + & 0.73 & + & 1.082 & + & 0.19 & - & 0.194 & - \\
\hline & & & & & & & & & \multicolumn{2}{|c|}{ Positive } & \multicolumn{2}{|c|}{0.506} \\
\hline PMMoV-16.9 & 1.567 & + & 1.296 & + & 0.864 & + & 0.915 & + & 0.138 & - & & - \\
\hline PMMoV-6.10 & 1.267 & + & 1.147 & + & 1.564 & + & 1.059 & + & 0.207 & - & 0.149 & - \\
\hline PMMoV-6.11 & 1.216 & + & 0.738 & + & 1.163 & + & 1.004 & + & 0.196 & - & 0.136 & - \\
\hline PMMoV-6.12 & 1.076 & + & 0.716 & + & 0.677 & + & 0.713 & + & 0.318 & - & 0.131 & - \\
\hline PMMoV-6.14 & 1.201 & + & 1.198 & + & 1.029 & + & 0.902 & + & 0.179 & - & 0.165 & - \\
\hline PMMoV-17.1 & 1.264 & + & 0.936 & + & 0.757 & + & 0.733 & + & 0.165 & - & 0.242 & - \\
\hline PMMoV-17.2 & 1.478 & + & 0.998 & + & 0.765 & + & 0.794 & + & 0.291 & - & 0.278 & - \\
\hline \multirow[t]{3}{*}{ PMMoV-17.3 } & 1.143 & + & 0.923 & + & 0.779 & + & 0.727 & + & 0.216 & - & 0.201 & - \\
\hline & & & & & & & & & \multicolumn{2}{|c|}{ Positive } & \multicolumn{2}{|c|}{0.577} \\
\hline & & & & & & & & & \multicolumn{2}{|c|}{ Negative } & \multicolumn{2}{|c|}{0.184} \\
\hline
\end{tabular}

only which can overcome $L^{+}, L^{1}$ and $L^{2}$ alleles.

\section{Pathotypes characterization based on CP gene sequence}

The sequences of each isolate obtained after custom sequencing were edited with vecscreen programme (http://www.ncbi.nih.gov/ vecscreen) to remove the vector sequences and subjected to BLAST analysis to make confirmation of the sequence as $\mathrm{CP}$ gene of $\mathrm{PMMoV}$.
The forward and reverse sequences were assembled manually. The obtained sequences corresponded to $\mathrm{PMMoV}$ region ranging from $5512 \mathrm{nt}$ to $6258 \mathrm{nt}$ containing $474 \mathrm{nts}$ long (5685-6158nt) CP gene of test PMMoV isolates. All the sequences have been submitted in NCBI database and allotted accession numbers (Table S2). As earlier workers have depicted the role of single amino acid mutations in PMMoV-CP in breaking the $L$ mediated resistance in pepper $[18,26]$ 


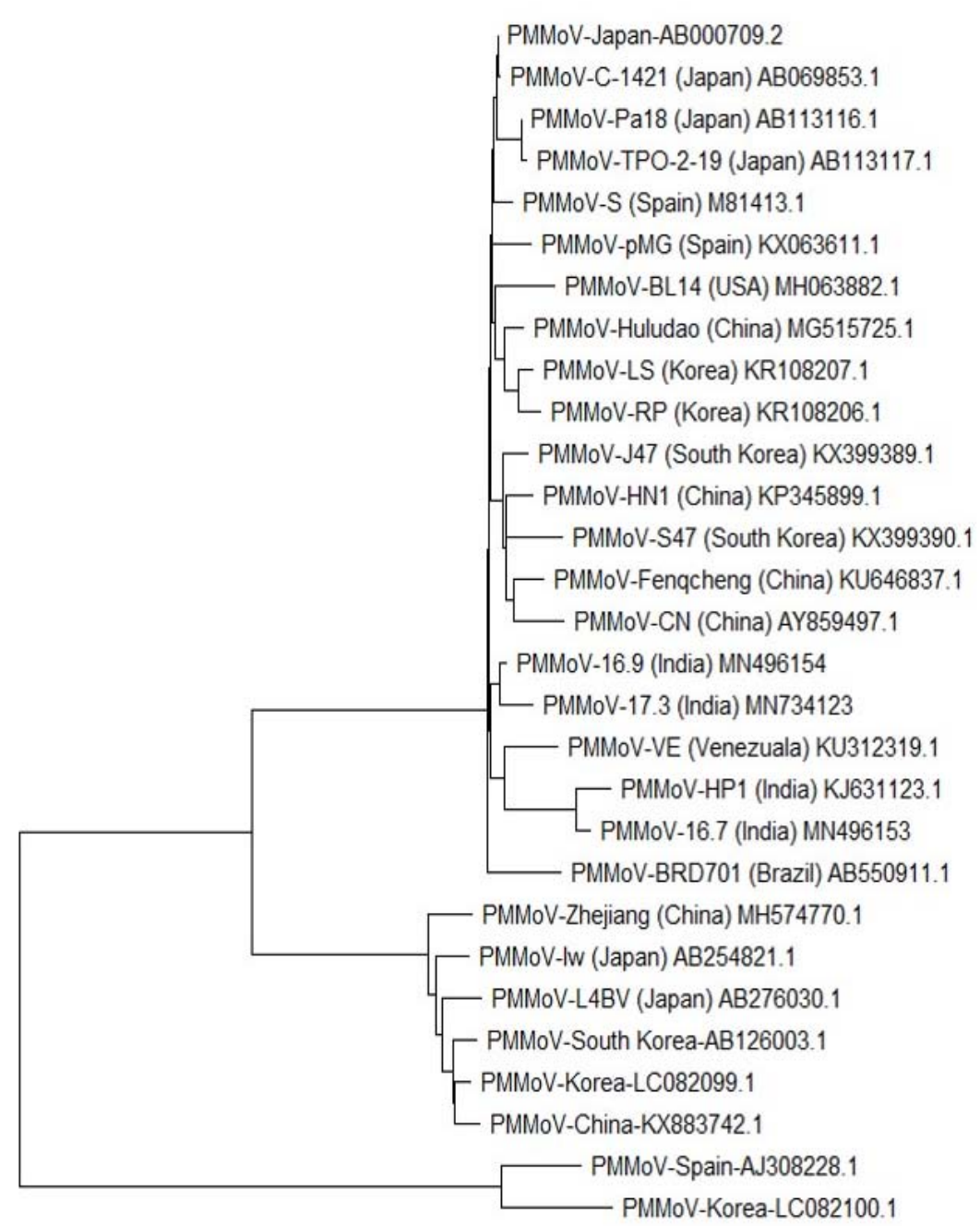

Figure 4: Phylogenetic tree constructed based on full genome sequence of PMMoV isolates using Geneious Prime software.

, the amino acid sequence of present isolates was determined using Expasy Translate tool. The amino acid sequences of all the test isolates along with $\mathrm{P}_{12}, \mathrm{P}_{123}$ and $\mathrm{P}_{1234}$ pathotypes available at NCBI database were aligned using ClustalW programme to elucidate amino acid mutations in CP region (Figure S1). Most of the nt substitutions shown were silent and did not result in any change in the amino acid. Though, the substitutions at 313th position of isolate PMMoV-16.6 (MK746118) and at 100th position of PMMoV-17.1 (MK746126) led to the substitution of Threonine to Alanine at 105th position of PMMoV-16.6 (MK746118) and Asparatic acid to Asparagine at 34th position of PMMoV-17.1 (MK746126). In case of PMMoV-16.10 (MK746122), substitution of Lysine to Arginine at 91st position was observed. The amino acid sequence of $\mathrm{CP}$ of all the present isolates except PMMoV-16.6, 16.10 and PMMoV-17.1 were 100 per cent similar to the $\mathrm{P}_{12}$ pathotypes available in NCBI database. The phylogenetic tree constructed using the amino acid sequences of the present isolates as well as $\mathrm{P}_{12}, \mathrm{P}_{123}$ and $\mathrm{P}_{1234}$ pathotypes of PMMoV through MEGAX software (Figure S2) clustered all the present isolates along with majority of $\mathrm{P}_{12}$ pathotypes in one clade. Other PMMoV- $\mathrm{P}_{123}$ and $\mathrm{P}_{1234}$ pathotypes were clustered separately in one clade. Earlier studies have revealed that the mutations either in the alpha helical bundle region of PMMoV-CP or in the regions corresponding to the outer surface of virus are responsible for affecting the viral elicitor activity [27]. In the present study, the single amino acid substitutions we obtained in the three PMMoV isolates were not found in the alpha helical bundle region or in the regions forming the outer surface of virus particle. Interestingly, they were located in the short and long hairpin loops that connect the left and right slewed helices and left and right radial helices, respectively which correspond to the inner surface of virus particle (Figure 3). Additionally, these 3 isolates were unable to cause any symptoms in $L^{3}$ and $L^{4}$ differentials as well as did not give positive reaction in DAS-ELISA as well as RT-PCR. Thus, based on the pathogenic response of test isolates on differential varieties and amino acid sequence of $\mathrm{CP}$ gene, all the 16 isolates were grouped in pathotype $\mathrm{P}_{12}$ of PMMoV. The existence of 3 pathotypes viz., $\mathrm{P}_{12}, \mathrm{P}_{123}$ and $\mathrm{P}_{1234}$ has been reported to infect capsicum in different parts of the world. So far, only 4 resistant alleles $L^{1}, L^{2}, L^{3}$ and $L^{4}$ are known to condition resistance in capsicum against tobamoviruses, In addition to these classical $L$ genes, another allele with different temperature sensitivity, $L^{1 a}$, was identified [11]. Out of the 3 pathotypes, $P_{12}$ is 
widely prevalent in majority of the countries followed by $\mathrm{P}_{123}$ and $\mathrm{P}_{1234}$. PMMoV-Br designated as $\mathrm{P}_{12}$ pathotype due to the resistant reaction on C. chinense 'PI 159236' and 'PI 22225' $\left(L^{3} L^{3}\right)$ and in $C$. chacoense 'PI 260429' $\left(L^{4} L^{4}\right)$ plants [28]. In another study, PMMoV P12 was reported on the basis of its inability to infect $C$. chinense PI159236 and C. chacoense PI260429 systemically and produced necrotic spots [29]. PMMoV isolate reported and characterized as $\mathrm{P}_{123}$ which is capable of breaking $L^{3}$ mediated resistance from Japan on the basis of its ability to produce mosaic on C. chinense PI159236 plants [30]. However in our study, none of the present PMMoV isolates produced visible symptoms like mosaic, mottling etc. on C. chinense PI159236 plants. P1234 pathotype of PMMoV reported from Israel on the basis of systemic symptoms produced on $C$. annuum 'Bosanova' $\left(L^{3} / l^{3}\right)$, C. chinense $159236\left(L^{3} / L^{3}\right), C$. annuum 'Luisiana' $\left(L^{4} / l^{4}\right)$, C. annuum 'Cuby' $\left(L^{4} / l^{4}\right)$ and C. annuum PI 1080 $\left(L^{4} / L^{4}\right)$ by PMMoV strain [17]. The new pathotype $\left(\mathrm{P}_{1234}\right)$ reported was capable of producing severe mosaic symptoms on pepper plants with $L 4$ genotype [17]. The occurrence of pathotype $\mathrm{P}_{12}$ in this part of the world may be attributed to the import of capsicum hybrid seed by different Agri-based companies for polyhouse cultivation. The introduction of PMMoV in India along with the import of Capsicum hybrid seeds [6]. The knowledge regarding the PMMoV pathotype will further aid in resistance breeding for sustainable management of this virus where the $L^{3}$ and $L^{4}$ genes can be employed in breeding programme. Although, it is also required to ascertain the pathotype of PMMoV isolates collected from other parts of the country.

\section{Phylogenetic and recombination analysis of full genome}

The full nucleotide sequences of three PMMoV isolates viz., collected from Mandi, Kullu and Shimla districts of H.P. The nucleotide sequences obtained were. The full genome sequences of three isolates PMMoV-16.7, 16.9 and 17.3 were submitted at NCBI database vide accession numbers PMMoV-16.7 (MN496153), PMMoV-16.9 (MN496154) and PMMoV-17.3 (MN734123) after assembly and BLASTn analysis. All the three isolates along with PMMoV-HP1 (KJ631123.1) shared 99 per cent similarity at nucleotide and amino acid level. In total all the 29 isolates including 4 from India and other from Spain, China, Japan, Korea, Brazil, US, Venezuela were analyzed for their phylogenetic relationship (Figure 4). The PMMoV-16.7 (MN496153) showed more than 99 per cent similarity with PMMoV-HP1 (KJ631123.1). The PMMoV-16.9 isolate (MN496154) shared maximum similarity with the Japanese isolate (AB000709.2) while PMMoV-17.3 (MN734123) isolate was most similar to PMMoV-16.9 isolate (MN496154). All the isolates from India were least similar to the Korean isolate (LC082100.1) with approximately 93 per cent similarity. All PMMoV isolates were grouped in three major clades (Figure 4). Clade I included two isolates viz., AJ308228.1 from Spain and LC082100.1 from Korea both capable of overcoming $L^{3}$ mediated resistance in pepper were included in clade II having $99 \%$ similarity. Clade II included isolates from Japan (AB254821.1, AB276030.1), China (KX883742.1, MH574770.1) and Korea (LC082099.1, AB126003.1) with more than $99 \%$ similarity. Clade III accommodated majority of the PMMoV isolates. PMMoV-HP1 (KJ631123.1), PMMoV-16.7 (MN496153), one isolate from Venezuela (KU312319.1), PMMoV16.9-MN496154 and PMMoV-17.3-MN734123), were clustered close to each other with $99 \%$ similarity. Other members in the clade included isolates from Brazil (AB550911.1), one from US (MH063882.1), two from Spain (M81413.1, KX063611.1), four from China (KP345899.1, KU646837.1, AY859497.1, MG515725.1), three from Korea (KX399389.1, KR108207.1, KR108206.1) and four from Japan (AB000709.2, AB069853.1, AB113116.1, AB113117.1) with $\sim 99 \%$ similarity. The recombination analysis using RDP3 software did not show any distinct recombination event in these 29 full genome sequences. RNA recombination has well notable role in virus evolution, viral genome variability and repair, depends on different host and environmental factors, precision rate of viral replicase proteins during viral replication, presence or absence of recombination hotspots in the viral genome [31]. The present results were in accordance with other workers who have found low or no recombination events in other tobamoviruses owing to the fact that tobamoviruses evolve at a very slow rate in nature $[32,33,34]$ (Fraile et al. 1996, 1997; Rao et al. 2017). The rate of viral recombination is an important consideration while framing the management strategy using host' genetic resistance as it is an important determinant of durability of host resistance [7].

\section{Conclusion}

The incidence and distribution of PMMoV has been escalated in H.P. in recent years. All the present popular cultivars cultivated by the farmers in the state are highly susceptible to the virus. The present study concludes the pathotype of PMMoV infecting bell pepper in H.P. state of India is $\mathrm{P}_{12}$. Additionally, the low recombination events were obtained in the full genome-based recombination analysis. Therefore, we recommend the recruitment of $L^{3}$ and $L^{4}$ genes in the breeding programmes as a sustainable management solution for this virus. However, the pathotype characterization studies of PMMoV infecting bell pepper in other parts of the country must be carried out to avoid the splaying of more virulent strains of this virus if present.

\section{Acknowlegdements}

The corresponding author is grateful to The Centro de Investigacion and Tecnologia Agroalimenatria de Aragon (CITA), Spain and National Bureau of Plant Genetic Resources (NBPGR), New Delhi for providing seeds of differential varieties. The research grant from University Grant Commission, New Delhi, India (award letter no.43-3/2014-SR) is also acknowledged.

\section{References}

1. Mckinney $\mathrm{HH}$. Two strains of Tobacco mosaic virus, one of which is seedborne in an etch-immune pungent pepper. Plant Disease Reporter. 1952; 36 : 184-187.

2. Wetter C, Conti M, Altschuh D, Tabillion R, Regenmortel MHV. Pepper mild mottle virus, a Tobamovirus infecting pepper cultivar in Sicily. Phytopathology. 1984; 74: 405-410

3. Colson P, Richet H, Desnues C, Balique F, Moal V, Grob JJ, et al. Pepper mild mottle virus, a plant virus associated with specific immune responses, fever, abdominal pains, and pruritus in humans. PLoS ONE. 2010; 5: e10041.

4. Balique $F$, Lecoq $H$, Raoult $D$, Colson $P$. Can plant viruses cross the kingdom border and be pathogenic to humans? Viruses. 2015; 7: 2074-2098.

5. Kitajima M, Sassi HP, Torrey JR. Pepper mild mottle virus as a water quality indicator. npj Clean Water. 2018; 1: 19.

6. Rialch N, Sharma V, Sharma A, Sharma PN. Characterization and complete nucleotide sequencing of Pepper Mild Mottle Virus infecting Bell Pepper in India. Phytoparasitica. 2015; 43: 327-337. 
7. Garcia-Arena F, McDonald BA. An analysis of the durability of resistance to plant viruses. Phytopathology. 2003; 93: 941-952.

8. Kang BC, Yeam I, Jahn MM. Genetics of plant virus resistance. Annu Rev Phytopathol. 2005; 43: 581-621.

9. Boukema IW. Allelism of genes controlling resistance to TMV in Capsicum. Euphytica. 1980; 29: 433-439

10. Boukema IW. Resistance to TMV in Capsicum chacoense Hunz. Is governed by allele of the L-locus. Capsicum Newsletter. 1982; 3: 47-48.

11. Sawada H, Takeuchi S, Matsumoto K, Hamada H, Kiba A, Matsumoto M, et al. A new Tobamovirus-resistance gene, $H k$, in Capsicum annuum. JJPN Soc Hortic Sci. 2005; 74: 289-294.

12. Kobayashi K, Sekine KT, Nishiguchi M. Breakdown of plant virus resistance: can we predict and extend the durability of virus resistance? J. Gen. Plan Pathol. 2014; 80: 327-336.

13. Wang D, Bosland PW. The genes of Capsicum. Horticulture Science. 2006; 41: 1169-1187.

14. Alonso E, Garcia-Luque I, de la Cruz A, Wicke B, Avila-Rincbn MJ, Serra MT, et al. Nucleotide sequence of the genomic RNA of Pepper mild mottle virus, a resistance-breaking Tobamovirus in pepper. J Gen Virol. 1991; 72 2875-2884.

15. Garcia-Luque I, Ferrero ML, Rodriguez JM, Alonso E, De La Cruz A, Sanz A et al. The nucleotide sequence of the coat protein genes and 3' non coding regions of two resistance-breaking tobamoviruses in pepper shows that they are different viruses. Arch Virol. 1993; 131: 75-88.

16. De la Cruz A, Lopez L, Tenllado F, Díaz-Ruíz JR, Sanz Al, Vaquero C, et al. The coat protein is required for the elicitation of the capsicum $L^{2}$ genemediated resistance against the tobamoviruses. Mol Plant Microbe Interact. 1997; 10: 107-113.

17. Antignus $\mathrm{Y}$, Lachman $\mathrm{O}$, Pearlsman $\mathrm{M}$, Maslenin $\mathrm{L}$, Rosner A. A new pathotype of Pepper mild mottle virus (PMMoV) overcomes the $L^{4}$ resistance genotype of pepper cultivars. Plant Dis. 2008; 92: 1033-1037.

18. Gilardi P, Garcia-Luque I, Serra MT. The coat protein of Tobamovirus acts as elicitor of both $L^{2}$ and $L^{4}$ gene-mediated resistance in capsicum. J. Gen. Virol. 2004; 85: 2077-2085.

19. Matsumoto $\mathrm{K}$, Sawada $\mathrm{H}$, Matsumoto $\mathrm{K}$, Hamada $\mathrm{H}$, Yoshimoto $\mathrm{E}$, Ito $\mathrm{T}$, et al. The coat protein gene of tobamovirus $\mathrm{P}_{0}$ pathotype is a determinant to activate temperature-insensitive $L^{1 a}$ gene-mediated resistance in Capsicum plants. Arch Virol. 2008; 153: 645-650.

20. Tomita R, Sekine KT, Mizumoto H, Sakamoto M, Murai J, Kiba A, et al. Genetic basis for the hierarchical interaction between Tobamovirus spp. and $L$ resistance gene alleles from different pepper species. Mol Plant Microbe Interact. 2011; 24: 108-117.

21. Sharma PN, Patiyal K, Rialch N, Rana D. Association of virus complex with capsicum under protected cultivation in Himachal Pradesh and implications in its management. Himachal Journal of Agricultural Research. 2016; 42: 47-51.
22. Clark MF, Adams AN. Characteristics of the microplate method of enzymelinked immunosorbent assay for the detection of plant viruses. J Gen Virol. 1977; 34: 475-83.

23. Thompson JD, Higgins DG, Gibson TJ. CLUSTAL W: improving the sensitivity of progressive multiple sequence alignment through sequence weighting, position-specific gap penalties and weight matrix choice. Nucleic Acids Res 1994; $22: 4673-4680$

24. Kenyon L, Kumar S, Tsai WS, Hughes JA. Virus Diseases of Peppers (Capsicum spp.) and their Control. Adv. Virus Res. 2014; 90: 297-354.

25. Soleimani $P$, Hosseini S, Hosseini A. Distribution of some viral disease on pepper (Capsicum annum) plants in Dezful fields from Iran. Bulletin of Environment, Pharmacology and Life Sciences. 2014; 3: 111-114.

26. Genda Y, Kanda A, Hamada H, Sato K, Ohnishi J, Tsuda S. Two amino acid substitutions in the coat protein of Pepper mild mottle virus are responsible for overcoming the $L^{4}$ gene-mediated resistance in Capsicum spp. Phytopathology. 2007; 97: 787-793.

27. Hamada H, Tomita R, Iwadate Y, Kobayashi K, Munemura I, Takeuchi S, et a . Cooperative effect of two amino acid mutations in the coat protein of Pepper mild mottle virus overcomes $\mathrm{L}^{3}$-mediated resistance in capsicum plants. Virus Genes. 2007; 34: 205-214.

28. Eiras M, Chaves ALR, Moreira SR, Araujo J, Colariccio A. Characterization of a non- $L^{3}$ gene-resistance breaking Pepper mild mottle virus isolate in capsicum. Fitopatologia Brasileira. 2004; 29: 670-675

29. Ruiz L, García C, Simon A, Janssen D. First report of a new pepper mild mottle virus pathotype 1,2 on pepper in Spain. J Plant Pathol. 2016; 98: 678698.

30. Elvira MI, Molina Galdeano M, Gilardi P, Garcia-Luque I, Serra MT. Proteomic analysis of Pathogenesis-Related proteins (PRs) induced by compatible and incompatible interactions of Pepper Mild Mottle Virus (PMMoV) in Capsicum chinense $L^{3}$ plants. J Exp Bot. 2008; 59: 1253-1265.

31. Nagy P. Recombination in Plant RNA Viruses. In M.J. Roossinck (ed.), Plant Virus Evolution. 2008; 133-156.

32. Fraile A, Malpica JM, Aranda MA, Rodriguez-Cerezo E, Garcıa Arenal F. Genetic diversity in tobacco mild green mosaic tobamovirus infecting the wild plant Nicotiana glauca. Virology. 1996; 223: 148-155.

33. Fraile A, Escriu F, Aranda MA, Malpica JM, Gibbs AJ, Garcia-Arenal F. A century of tobamovirus evolution in an Australian population of Nicotiana glauca. J Virol. 1997; 71: 8316-8320.

34. Rao L, Guo Y, Zhang L, Zhou X, Hong J, Wu J. Genetic variation and population structure of Cucumber green mottle mosaic virus. Arch Virol. 2017; 62: 1159-1168. 